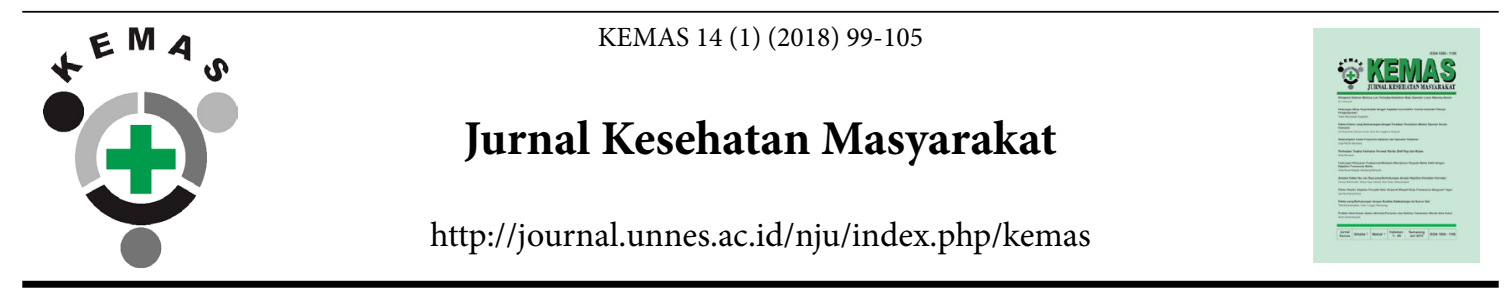

\title{
Improvement of Nutritional Quality of Tuber Flour as Local Food Resource
}

\author{
Etty Soesilowati ${ }^{1 \bowtie}$, Nana Kariada Tri Martuti ${ }^{1}$, Octavianti Paramita ${ }^{1}$ \\ ${ }^{1}$ Universitas Negeri Semarang
}

\begin{tabular}{l} 
Article Info \\
\hline Article History: \\
Submitted January 2018 \\
Accepted April 2018 \\
Published July 2018 \\
\hline Keywords: \\
quality, tuber flour, \\
local food \\
\hline DOI \\
https://doi.org/10.15294/ \\
kemas.v14i1.12991
\end{tabular}

\begin{abstract}
Tuber plants are sources of carbohydrates which could be used as strategic national food reserves. Beside high carbohydrates, tubers also contain a number of bioactive compounds which have physiological effects as antioxidants. This research aimed to develop tuber flour products and increase additional value through the use of appropriate technology and diversification of processed products. Research samples were 16 tuber species. The method was crystallisation by utilization of blower system to accelerate the process of water content reduction. The data were analyzed using proximat analysis. Water content was $5.61-15 \%$, ash content was $0.4-5.31 \%$, carbohydrate content was $82-88 \%$, protein content was $0.67-6.32 \%$, and fat content was $1-7 \%$. The result showed that chemical content of Suweg flour with pragelatinization method at $70^{\circ} \mathrm{C}$ for 60 minutes had the highest water, ash, and fiber content which were $5.79 \%, 2.49 \%$, and $43.73 \%$, respectively. Meanwhile, the highest carbohydrate content obtained by heating for 10 minutes was $25.80 \%$. Tubers flour is worthy to be used as raw materials for food industry.
\end{abstract}

\section{Introduction}

The diversity of processed products based on flour causes flour production and demand for wheat to increase in proportion to the level of public consumption and the rate of population growth. National flour consumption rate based on data from Indonesian Association of Flour Merchant/Asosiasi Pengusaha Terigu Indonesia (APTINDO), grew until the first semester of 2014, which amounted to 2.79 Metric Tons (MT) equivalent to 3.7 MT of wheat. That number grew by $5.4 \%$ compared to the first semester of 2013. The growth in the consumption of wheat flour is due to the fact that it is widely used in the manufacture of foods such as bread, cakes, noodles, biscuits (Nainggolan \& Jordikson, 2017).

APTINDO notes that there were additional 5 new flour mills starting production in 2014. The new plant will increase production capacity and increase wheat imports as flour raw material. APTINDO Chairman Franciscus Welirang said that domestic wheat production currently reaches 5.4 million tons per year, equivalent to 7 million tons of wheat per year. With additional investment of the five companies, the wheat imports will increase to 9.7 million tonnes of wheat per year or an increase of $38 \%$. Wheat is a food that is $100 \%$ imported by Indonesia (Evie, 2013).

Data from Statistic Central Agency (Badan Pusat Statistik) showed that import of wheat and meslin as of April 2017 reached 934.7 thousand tons with value of US \$ 214.04 million. The imports increased substantially compared to the same month's imports of the

\begin{tabular}{lr}
\hline Correspondence Address: & pISSN 1858-1196 \\
Universitas Negeri Semarang. & eISSN 2355-3596 \\
Email : ettysoesilowati@yahoo.com &
\end{tabular}


same commodity. Meanwhile in March 2017, imports of wheat and meslin only reached 741.3 thousand tons with value of US \$ 167.2 million. This meant that there was an increase of 193.4 thousand tons.

If the data were specified by country of origin, the highest amount of Indonesian wheat and meslin imports come from Australia as much as 656.5 thousand tons with a value of US \$ 145.1 million. Second, from Canada which amounts to 114.5 thousand tons with a value of US \$ 30.1 million. Third, from the United States (US) which amounts to 66.2 thousand tons worth US \$ 17.08 million. Fourth, from Ukraine which amounts to 54.6 thousand tons with a value of US \$ 11.9 million. While the imports from other countries reached 42.8 thousand tons with a value of US $\$ 9.72$ million. Cumulatively, the total import from January to April 2017 was 3.30 million tons with a value of US \$ 740.5 million. It was lower compared to January-April 2016 which amounted to 3.75 million tons with a value of US $\$ 866.3$ million.

In order to produce one ton of wheat flour, it requires seven million tons of wheat imports. Fifty five percent of wheat flour is absorbed by noodle producers, while bread producers are $22 \%$ and biscuits are $18 \%$. The majority of wheat imports are from Australia, Canada, America, Russia, Ukraine, Kazakhstan, India, Pakistan, Brazil, and Argentina. Statistic Central Agency announced that the value of wheat imports in January 2016 were recorded to be worth of 443.4 million US dollars or increase drastically by $86.35 \%$.

The dependence of Indonesian people on flour which is wholly made from imported wheat, is feared will gradually shift the consumption of local food besides rice. Local carbohydrate sources that can actually function strategically as food reserves and support national food security are tubers. Tubers are feared to be more neglected in the future.

In 2014, Agriculture Technology Research Office/Balai Pengkajian Teknologi Pertanian (BPTP) of Central Java Province managed to list 13 types of specific genetic resources of potential non-rice food crops in Central Java, where 10 tubers plant have not been utilized optimally.

Maratirrosyidah \& Teti (2015) found that gembili, gadung, ubi kayu, garut, and kimpul are inferior local tubers widely available in Indonesia, but the availability was not directly proportional to their utilization. Inferior local tubers beside contain high carbohydrates, they also contain a number of bioactive compounds that have physiological effects as antioxidants. Bioactive compounds present in inferior local tubers include dioscorin, diosgenin, and phenol. These bioactive compounds have been shown to have the ability to prevent free radicals.

Furthermore, Pabowo et al., (2014) found that in comparison with wheat flour, gembili flour has the same economic level. With existing technology, gembili can produce

Table 1. Specific Genetic Resource Diversity of Non-Rice Food Crops in Central Java.

\begin{tabular}{clll}
\hline No & Local Name & Scientific Name & Geographical Distribution \\
\hline 1 & Ubi Kayu Sulawi & Manihot utilissima & Wanayasa Subdistrict, Banjarnegara Regency \\
2 & Ubi Kayu Marekan & Manihot utilissima & Pagetan Subdistrict, Banjarnegara Regency \\
3 & Kedelai Hitam Losari & Glycine max & Losari Subdistrict, Brebes Regency \\
4 & Kedelai Grobogan & Glycine max (L) Merrill & Grobogan Regency, Jawa Tengah \\
5 & Jagung Jali & Coix lachryma-jobi & Tembarak Subdistrict, Temanggung Regency \\
6 & Wilus & Dioscores alata & Mojogedang Subdistrict, Karanganyar Regency \\
7 & Uwi Ungu & Dioscores alata & Bojong Subdistrict, Tegal Regency \\
8 & Uwi Pandan & Dioscores alata & Pangetan Subdistrict, Banjarnegara Regency \\
9 & Gembili & Dioscores esculenta & Bojong Subdistrict, Tegal Regency \\
10 & Ganyong & Canna edulis & Jatipuro Subdistrict, Karanganyar Regency \\
11 & Garut & Marantha arundinaceae & Jumantono Subdistrict, Karanganyar Regency \\
12 & Porang & Amorphophallus muelleri & Jenawi Subdistrict, Karanganyar Regency \\
13 & Suweg & Amorphophallus campanulatus & Mojogedang Subdistrict, Karanganyar Regency \\
\hline Source: BPTP of Central Java Province (2014) &
\end{tabular}


$25 \%$ immersion. Gembili can be processed into chips and flour which are suitable for cake and bread production. Another advantage of gembili are its high carbohydrates content and bioactive compounds. There are several bioactive compounds such as water soluble polysaccharides, dioscorin and diosgenin that can be utilized for the health of the body. The content of bioactive compounds can serve as immunomodulators and prevention of metabolic disease (hypercholesterolemia, dyslipidemia, diabetes and obesity), inflammation, and cancer.

Tuber as a source of local food is an organ of plants that serves as a storage of carbohydrate substances. Based from the shape of the tubers, it can be divided into three categories, namely: (1) Bulbus, which is a bulb formed from stack of leaves base, it is usually produced by family Alliaceae, Amaryllidaceae, and Liliaceae; (2) Stem tuber, which is formed from modified stems which grows beneath the surface of the soil, enlarge, and contain many starches and is usually produced by several species of Solanaceae and Asteraceae; (3) Tuberous root, which is a tuber formed from root modification. (Paramita, 2012)

The types of tubers that have been cultivated and had commercial status are cassava (Manihot esculenta), sweet potato (Ipomea batatas), and taro (Colocasia esculenta); while example of tubers which are grouped into vegetable crops is potatoes (Solanum tuberosum). Most other types of tubers are cultivated only with subsistence or semi-commercial status such as garut (Maranta arundinacea), ganyong (Cana edulis), gadung (Dioscorea hispida), uwi (Dioscorea alata), gembili (Dioscurela esculenta), uwi katak (Dioscorea pentaphyla), kimpul (Xanthosoma violeceum), talas belitung (Xanthosoma saggitifolium), and suwek (Amorphophalus companulatus).

Santi et al., (2017) found 44 types of traditional food made from tubers circulating in the city. The average nutrient content (energy, protein and fat) of the traditional food made from the raw material per serving size were energy of 88 to $502 \mathrm{kcal}$, protein of 0.60 to 5.60 $\mathrm{g}$ and fat of 0.30 to $28,10 \mathrm{~g}$. A study by Budiono (2013) also found that the average of Nutrition
Development Index in Semarang City was only 0.701 (medium category), with each dimension were: nutritional status of 0,947 (good), energy consumption and nutrients of 0.458 (less), food safety of 0.729 (medium), lifestyle of 0.672 (medium).

The problems are: (1) Tuber as substitute for rice/flour is less preferred even though the price is cheaper because it looks unattractive, uncomfortable, and had limited processing; (2) Water content of tuber when it is harvested usually reaches $\pm 65 \%$ so it is easily damaged, the appearance would be blackish blue spots, browning, soft (easly oxidized), moldy and eventually become rotten; and (3) Not all tubers show physiochemical content corresponding to the amount of carbohydrates required by the body.

The research "Improvement of Physiochemical Quality of Tubers Flour as Local Food Resources" was needed with the aim of: (1) improving the quality of the physiochemical content of tuber flour as required; and (2) improving the siege process through the utilization of appropriate technology. The research is expected to be useful to improve the nutritional status \& national food security on the one hand, and on the other side can be utilized local resources as raw material of food industry.

\section{Method}

The experiment used an experimental approach by developing dryers and laboratory tests. Tuber dryer was developed by integrating blower system, temperature, and fire quantity from the stove automatically.

In order to know the nutritional value of dried tuber chips, we used 16 types of tubers, namely bentoel, garut, ganyong, gadung, kimpul, black potato, potato, cassava tubers, suweg, taro, yellow sweet potato, white sweet potato, purple sweet potato, uwi, cantel (shorgum) and breadfruit. The water content was determined directly by weighing and drying the tubers at $105^{\circ} \mathrm{C}$ for 6 hours and then cooled to determine the fixed weight.

Analysis of protein content used MicroKjeldahl method. At first the sample was weighed and laid into Kjeldahl flask, $50 \mathrm{mg}$ $\mathrm{HgO}, 2 \mathrm{mg} \mathrm{K}_{2} \mathrm{SO}_{4}, 2 \mathrm{ml}$ of $\mathrm{H}_{2} \mathrm{SO}_{4}$, boiling stone, and boiled for 1.5 hours. After solution chilled, 
diluted with aquadest. Samples were distilled by addition of 8-10 ml of $\mathrm{NaOH}-\mathrm{Na}_{2} \mathrm{~S}_{2} \mathrm{O}_{3}$ solution. The distillation product was accommodated with an erlenmeyer containing $5 \mathrm{ml}$ of $\mathrm{H}_{3} \mathrm{BO}_{3}$ and 2-4 drops of indicator (mixture of 2 parts methyl red $0.2 \%$ in alcohol and 1 part methyl blue $0.2 \%$ in alcohol). The obtained destilate was titrated with a $0.02 \mathrm{~N} \mathrm{HCl}$ solution until it turned gray. The results obtained were in total N, whose values can be calculated by the formula: Protein Contain (\%) =

(ml HCL x ml Blank) N HCl x 14.007 x 100 x 6.25

Analysis of fat content used Soxhlet method. Samples were weighed and wrapped with filter paper and included in the Soxhlet extraction apparatus along with diethyl ether. Further refluxed for 6 hours until the solvent was clear colored. The solvent in the fat flask was distilled off, and heated in an oven at $105^{\circ} \mathrm{C}$ until the solvent evaporated all. Once cooled in a desiccator, the fat flask was weighed until it obtained a constant weight.

Analysis of ash content of food material was determined by weighing the remaining minerals from organic matter combustion at a temperature of $550^{\circ} \mathrm{C}$. The sample was weighed and put in a porcelain cup. Then the cup and samples were burned in the smoke chamber until smoke was not present and is ashed at 550 ${ }^{\circ} \mathrm{C}$ until the color turned light gray and have constant weight. Then it was cooled down again in the desiccator and weighed after it reached room temperature.

Carbohydrate Level Analysis was calculated by difference method by reducing $100 \%$ nutrient content of sample with water content, ash content, protein content, and fat content. The value can be determined using the following formula: Carbohydrate Level $(\%)=100 \%-($ Water Content + Ash Content + Protein Level + Fat Level)

\section{Results and Discussion}

Drying is the process of moving heat from the dryer air to the material and evaporation of the water content from the material into the dryer air simultaneously. Heat movement can take place by convection, conduction, and radiation. Drying using a drying apparatus has several advantages: the material can be more durable, thus more resistant during storage and the volume of the material becomes smaller making it easier and space saving during

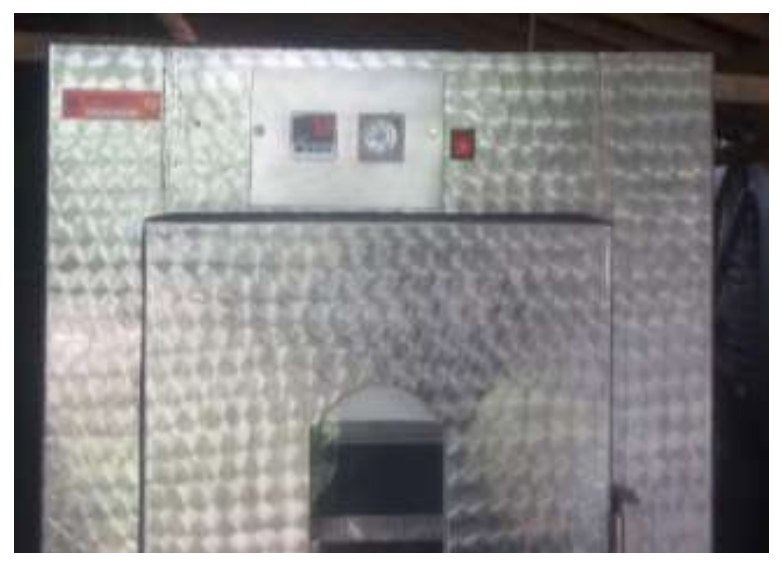

Figure 1. Function Button on the Dryer

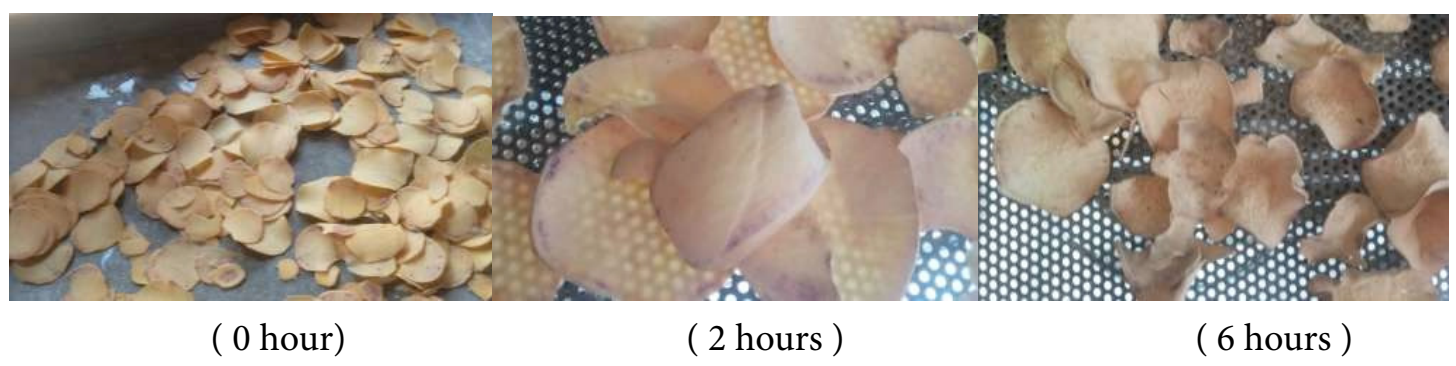

Figure 2. Condition of Tuber Chips in Drying Process 
packing and transporting.

The results of this study showed that in order to obtain dry chips material with unchanged tuber base color took 8 hours. This condition indicated that the nutrient content of flour had not changed much. Yu et al., (2006) explained that the old drying process would cause damage to protein such as denaturation, structure aggregation, and reduced rehydration enzyme activity. Protein damage is characterized by changes in the entire secondary structure of proteins.

One of the parameters that determines the nutritional value of food is the amount and variety of nutrients contained in food. Proximate analysis is one of chemical analysis method to identify the content of a food substance from a feed or food ingredient. Table 2 shows nutritional information of floures from local tuber, which were analyzed using proximate analysis of ash content to know the content of macronutrient, namely carbohydrate, protein, fat, water and micronutrient.

Based on the results of proximate analysis, the average moisture content of Suweg Flour was lower than that of the other tuber. Conversely, black potato flour and potato flour have high water content compared with other flour which were $13.7 \%$ and $13.0 \%$, respectively.
Flour of tubers with low moisture content might be stored longer, so they could be sold or used as needed. The presence of water in a food material is the main parameter involved in most food-damaging reactions. Water content is a factor affecting the appearance, texture, taste, endurance, freshness, and consumer acceptance.

The results also showed that the average sample proximate analysis of ash content on Tuber Flour was better than Wheat Flour which was only $0.59 \%$. The average ash concentration of Kimpul flour (3.16\%) was higher than Bentoel Flour (3.46\%) and Uwi Flour (2.36\%). The purpose of the measurement of ash content in food material were: (1) to know the index of flour purity, (2) to know the index of purity, (3) to detect the presence of forgery and (4) as a parameter of cleanliness of contamination. The ash content in a food material could indicate the presence of inorganic mineral contents that have high resistance to the cooking temperature. Ash from natural organic compounds, which is an inorganic residue from combustion, has several main components that are commonly found, namely potassium, sodium, calcium, magnesium, manganese, and iron. Ash content describes the total mineral content of macronutrient and micronutrient.

Table 2. Proximate Content List of Tuber Flours

\begin{tabular}{lllllll}
\hline No. & Name & $\begin{array}{l}\text { Water } \\
\text { content }(\%)\end{array}$ & $\begin{array}{l}\text { Ash content } \\
(\%)\end{array}$ & $\begin{array}{l}\text { Protein } \\
(\%)\end{array}$ & Fat $(\%)$ & $\begin{array}{l}\text { Carbohydrate } \\
(\%)\end{array}$ \\
\hline 1. & Bentoel Tubers & 5.61 & $\mathbf{3 . 4 6}$ & $\mathbf{0 . 8 6}$ & 4.62 & 85.45 \\
2. & Garut Tubers & 7.22 & 1.27 & 0.67 & 3.54 & 87.31 \\
3. & Ganyong Tubers & 7.42 & 1.37 & 0.44 & 6.43 & 84.34 \\
4. & Gadung Tubers & 6.06 & 0.55 & 6.32 & 14.23 & 60.80 \\
5. & Kimpul Flour & 6.91 & 3.61 & 0.58 & 2.48 & 86.42 \\
6. & Black Potato Flour & 13.78 & 2.08 & 4.21 & 13.04 & 85.7 \\
7. & Potato Flour & 13 & 0.4 & 0.3 & 0.1 & 85.6 \\
8. & Cassava Flour & 9.1 & 1.3 & 1.6 & 0.5 & 88.2 \\
9. & Suweg Flour & 5.13 & 1.63 & 0.55 & 5.48 & 87.22 \\
10. & Taro Flour & 10.72 & 2.63 & 4.74 & 12.44 & 58.14 \\
11. & Yellow Cassava Flour & 10.17 & 4.71 & 4.22 & 0.91 & 83.19 \\
12. & White Cassava Flour & 10.99 & 3.14 & 4.46 & 1.02 & 84.83 \\
13. & Purple Cassava Flour & 7.28 & 5.31 & 2.79 & 0.81 & 83.81 \\
14. & Uwi Flour & 7.14 & 2.36 & 0.8 & 3.64 & 85.59 \\
15. & Cantel Flour & 11.65 & 1.21 & 3.68 & 21.8 & 48.95 \\
16. & Breadfruit Flour & 15 & 2 & 3.6 & 0.8 & 78.90 \\
\hline
\end{tabular}

Source: data processed 
The average protein content of tuber flour was much lower than wheat flour (13.5\%). Protein is one of closely related variable to nutritional status beside maternal knowledge and family income (Elisa, 2012). Tubers also do not contain gliadin and glutenin proteins that form gluten in Wheat Flour, so the flour of potential tubers could be used as raw material of products that do not require development process. Protein is a source of amino acids which contains $\mathrm{C}, \mathrm{H}, \mathrm{O}$, and $\mathrm{N}$ elements that are not owned by fat and carbohydrates. Tubers are not source of protein because of the protein content are low. Tuber flour can be used as an alternative raw material of processed food through food nutrification such as fortification, supplementation or protein supplementation, until the protein value of processed food increases (BPTP, 2014).

Fat is a heterogeneous component of food, therefore the analysis of fat constituent components could become very complex. Fat is classified as lipid group which is insoluble in water but tends to dissolve in organic solvents such as benzene, ether, and chloroform. Fat is more important as source of energy than protein and carbohydrate because one gram of oil or fat can produce $9 \mathrm{kcal}$ of energy, while protein and carbohydrate only produce $4 \mathrm{kcal}$. In examination of fatty acid content of tubers, the result showed that fat content of potato, cassava, and sweet potato tubers were low (1 $1.1 \%)$. Meanwhile, other tubers had higher fat content than wheat flour content $(1.07 \%)$.

Carbohydrate is a polyhydroxyaldehyde or polyhydroxyketone that plays an important role in nature because it is the main energy source for human and animals. Carbohydrates belong to the nutrient component which acts as main source of energy supply for the body. The average carbohydrate content of tubers flour were above $48 \%$. Most carbohydrate levels of the tuber flour are in the range of $82-88 \%$. Tubers are one type of carbohydrate source beside rice and corn. Tuber flours with high carbohydrate content provide opportunity for diversification of raw material for processed food source of carbohydrate, which can be processed according to physical characteristic and physiochemistry of each flour. A study by Paramita \& Anggraini (2017) also recommended usage of Mokaf Flour as an analog rice with good nutritional content. Another advantage of sweet potatoes is its sufficient content of vitamins B, namely vitamin B6 and folic acid. Both vitamins are needed to optimize the work of the brain to maintain good memory. Sweet potatoes are rich in fiber and complex carbohydrates, but low in calories. These characteristics are very beneficial for diabetic patients because it can control or slow the increase in blood sugar levels of diabetic patients. An anthocyanin group stored in sweet potatoes is able to block the rate of free radical destruction caused by nicotine, air pollution, and other chemicals. Antosianin plays a role in preventing aging, memory loss and dementia, polyp formation, uric acid accumulation, stomach ulcer formation, coronary heart disease, cancer and degenerative diseases, such as atherosclerosis. In addition, anthocyanins also have antimutagenic and anticarcinogenic properties against variety of mutagens and carcinogens that present in food materials and their processed products. It also could prevent disruption of liver function, acts as antihypertensive, and lowers blood sugar levels (Evie, 2013).

Sweet potatoes as potential raw material for food industry is abundant in number. It has satisfactory nutrient content and components which are beneficial for physiological function such as anthocyanin and karatenoid which could act as antioxidant and fine fiber which has prebiotic function. (Rosidah, 2014) Tuber farming is actually feasible to be developed because it is profitable. A study by Sunandar et al., (2016) showed that the income of tuber farmers for each planting season was Rp 7667487.30/0.31 hectare with an average production amount of $2006.46 \mathrm{~kg}$. The average income per hectare was Rp 24733830.01/ hectare and average production of $6472.44 \mathrm{~kg}$ with value of R/C Ratio $>1$ or 2.02 .

\section{Conclusions}

The results of the study on 16 types of tuber flours, which include Bentoel Flour, Garut flour, Ganyong flour, wheat flour, Kimpul flour, black potato flour, potato flour, cassava flour, Suweg flour, taro flour, yellow sweet potato flour, white sweet potato flour, purple sweet potato flour, Uwi flour, Cantel 
flour and Breadfruit flour showed several physiochemical contents which were: (1) tuber flours had low water content, therefore it could be stored longer; (2) the average sample proximat analysis of ash content of tuber flours was better than wheat flour which was only $0.59 \%$; (3) the average protein content of local tuber flour was much lower than wheat flour $(13.5 \%)$, therefore tuber flours could not be processed into processed products that require development/fermentation process; (4) the fat content of tuber flours was not too low (1-7\%) and was more than wheat flour (1.67\%); (5) average carbohydrate content of local tubers was above $48 \%$ and most carbohydrate levels of the tuber flour were in the range of $82-88 \%$.

From the results of this study, we suggest that: (1) tuber flours should be processed and used as substitute for rice and wheat flour and can be consumed every day; (2) further studies are needed regarding the use of tuber flour in non-food industries to further increase the economic value of tubers; and (3) it needs a government policy to increase quantity, quality, and continuity of tuber supply as raw material for food and non-food industry by involving related stakeholders.

\section{References}

BPTP. 2014. Peran Inovasi Teknologi Pertanian dalm Pengembangan Bioindustri Berkelanjutan untuk Mewujudkan Kedaulatan Pangan. Prosiding Produksi BPTP Jawa Tengah, 1

Budiono, I., 2013. Pengembangan Indeks Pembangunan Gizi. Jurnal Kesehatan Masyarakat, 8 (2).

Elisa, P., 2012. Determinan Status Gizi Pada Siswa Sekolah Dasar. Jurnal Kesehatan Masyarakat,
$7(2)$.

Evie, F.P., 2013. Pemanfaatan Antioksidan dan Betakaroten Ubi Jalar Ungu Pada Pembuatan Minuman non-Beralkohol. Media Gizi Masyarakat Indonesia, 2(2), pp. 54-57.

Mar'atirrosyidah, R., \& Teti, E., 2015. Aktivitas Antioksidan Senyawa Bioaktif Umbi Lokal Inferior. Jurnal Pangan dan Agroindustri, 3(2), pp.594-601.

Nainggolan, H., \& Johdikson, A., 2017. Analysis of Integration of Cassava Agribusiness Subsystem at Pancur Batu Sub-district Deli Serdang Regency. Agrium, 20(3).

Paramita, \& Anggraini, M., 2012. Pembuatan Data Base Fisiokimia Tepung Umbi-umbian di Indonesia Sebagai Rujukan Diversifikasi Pangan. Jurnal Saintek, 10(1).

Prabowo, A.Y., Estiasih, T., \& Purwantiningrum, I., 2014. Gembili, Bahan Pangan Mengandung Senyawa Bioaktif. Jurnal Pangan dan Agroindustri, 2(3), pp.129-135.

Rosidah, 2014. Potensi Ubi Jalar Sebagai Bahan Baku Industri Pangan. Tehnoboga, 1(1).

Santi, N., Widara, S.S., \& Budijanto, S., 2017. Analogue Rice as the Vehicle of Public Nutrition Diversity. Jurnal Kesehatan Masyarakat, 13(1).

Sunandar, M.M., Darman, S., \& Antara, M., 2016. Income Analysis and Development Strategy of Banggai Yum Farming System in South Totikum Sub District of Banggai Kepulauan District. Journal Agroland, 23 (3), pp. 208 217.

Yu, J., Starr, D.A., Wu, X., Parkhurst, S.M., Zhuang, Y., Xu, T., Xu, R., \& Han, M., 2006. The KASH Domain Protein MSP-300 Plays an Essential Role in Nuclear Anchoring During Drosophila Oogenesis. Dev. Biol., 289(2), pp.336-345 